\title{
Rapid method of total RNA mini-preparation from eucaryotic cells
}

\author{
Wolfgang Walther, Ulrike Stein ${ }^{1}$ and Wolfgang Uckert* \\ Department of Molecular Tumour Therapy and ${ }^{1}$ Department of Molecular Resistance Mechanisms, \\ Max-Delbrück-Centre for Molecular Medicine, Robert-Rössle-Straße 10, 1115 Berlin, Germany
}

Received January 7, 1993; Revised and Accepted February 22, 1993

There have been described a wide variety of methods for the preparation of total RNA from eucaryotic cells $(1,2)$. These methods are mainly designed for the isolation of RNA from relatively large amounts of cells. In a situation of screening a large number of cell clones, minimized cell cultivation effort and preparation time for total RNA isolation will be of great advantage.

We developed a method which fulfils the following criteria: (i) the procedure is very simple, (ii) includes short incubation and reaction times, (iii) needs relatively small amounts of cells and (IV) can be carried out for a great number of cell clones as a multi-sample preparation. We used the rapid method mainly to screen human tumour cell clones for their expression of foreign genes after transfection or transduction of various vector constructs.

The brief protocol is the following:

Individual clones were seeded into 12 well dishes. After 24 days cultures reached confluence and contained approximately $5 \times 10^{5}$ cells per well. For the RNA preparation the medium was discarded and cells were washed once with $1 \mathrm{ml}$ of $0.9 \%$ sodium chloride solution. Then $200 \mu \mathrm{l}$ of lithium chloride/urea solution ( $3 \mathrm{M} \mathrm{LiCl}, 6 \mathrm{M}$ urea) (3) were added to each well and incubated for $5 \mathrm{~min}$ at $20^{\circ} \mathrm{C}$. This was followed by addition of $1 / 10 \mathrm{vol}$. of $3 \mathrm{M}$ sodium acetate solution and of $2.5 \mathrm{vol}$ of absolute ethanol. After mixing the suspension was transferred into an $1.5 \mathrm{ml}$ Eppendorf tube, left for $15 \mathrm{~min}$ at $20^{\circ} \mathrm{C}$ and centrifuged at 12000 $\mathrm{rpm}$ for $5 \mathrm{~min}$. The supernatants were discarded and the pellets were resuspended in $100 \mu \mathrm{l}$ of TES $(10 \mathrm{mM}$ Tris pH 7.6, $1 \mathrm{mM}$ EDTA, $0.5 \%$ SDS; autoclaved) by vortexing thoroughly. Then $100 \mu \mathrm{l}$ of phenol/chloroform were added followed by vortexing and centrifugation of the probes at $12000 \mathrm{rpm}$ for $5 \mathrm{~min}$. The aqueous phase was transferred into another Eppendorf tube, 1/10 vol. of $3 \mathrm{M}$ sodium acetate and $2.5 \mathrm{vol}$. of absolute ethanol were added and stored at $-70^{\circ} \mathrm{C}$ for $15-20 \mathrm{~min}$ to precipitate the RNA. Probes were then centrifuged at $12000 \mathrm{rpm}$ for $10 \mathrm{~min}$. Pellets were washed once with $1 \mathrm{ml}$ of $70 \%$ ethanol, dried and resuspended in $20-40 \mu \mathrm{l}$ of DEPC - water and stored at $-20^{\circ} \mathrm{C}$ for further investigations. The RNA yields were calculated by OD-260 spectrophotometry and ranged between 10-15 $\mu \mathrm{g}$.

As shown in Figure 1A the quality of the RNA obtained by this method is comparable to material isolated by more time consuming procedures. The characteristic discreet $28 \mathrm{~S}$ and $18 \mathrm{~S}$ bands in the agarose gel (Figure 1A) show that the isolated RNA is intact. Contamining genomic DNA has not been found, so that

the lithium chloride treatment eliminated the genomic DNA in the samples although cells were not homogenized or sonicated to shear the DNA. Figure 1B demonstrates that the mini-prep RNA is suitable for Northern blot hybridization procedures with comparable results to established methods: the RNA preparations shown in Figure 1A were blotted onto nitrocellulose filters and hybridised with a CEA (carcinoembryonic antigen)-specific ${ }^{32} \mathrm{P}$ labelled DNA probe. We further performed incubations at $37^{\circ} \mathrm{C}$ for $48 \mathrm{hr}$ and found that the RNA is stable and nuclease-free. The advantage of this protocol is the rapidity $(1.5 \mathrm{hr})$ and the possibility to prepare a large number of samples in parallel. Thus the method may be of interest for expression studies in mammalian cells on qualitative or quantitative level.

\section{REFERENCES}

1. Maniatis,T., Fritsch,E.F. and Sambrook,J. (1982) Molecular Cloning: $A$ Laboratory Manual. Cold Spring Harbor Laboratory Press, Cold Spring Harbor. NY.

2. Ullrich,A., Shine,J., Chirgwin,J., Pictet,R., Tischer,E., Rutter,W.J. and Goodman,H.M. (1977) Science 196, 1313-1319.

3. Auffray,C. and Rougeon,F. (1980) Eur. J. Biochem. 107, 303-314.

A

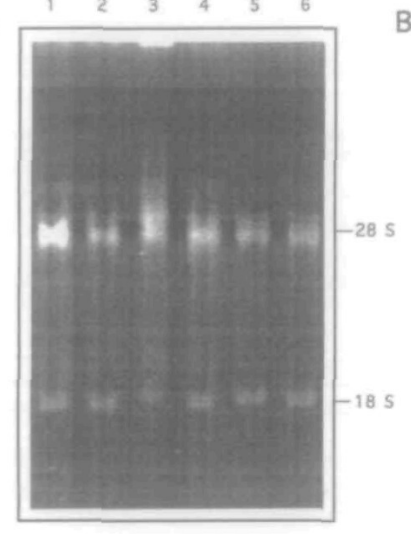

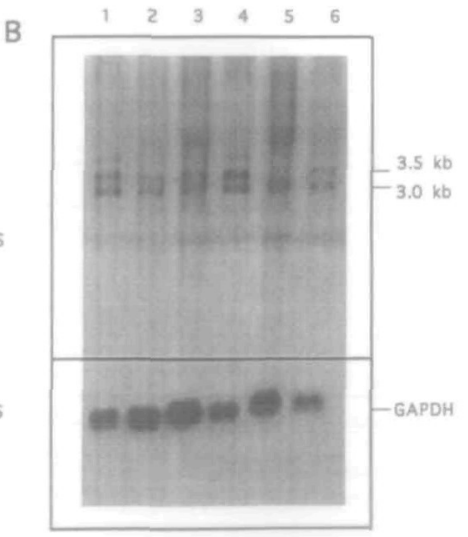

Figure 1. (A) Agarose gel electrophoresis of RNAs prepared by the procedure as described by Auffray and Rougenon (lanes 1,2,3) and by the mini-preparation protocol (lanes 4, 5, 6). (B) Northern blot analysis of these RNAs with a CEA (carcinoembryonic antigen)-specific DNA probe. The bands of $3.5 \mathrm{~kb}$ and 3.0 $\mathrm{kb}$ correspond to CEA-transcripts. GAPDH: Glyceraldehyde-phosphate dehydrogenase.

* To whom correspondence should be addressed 